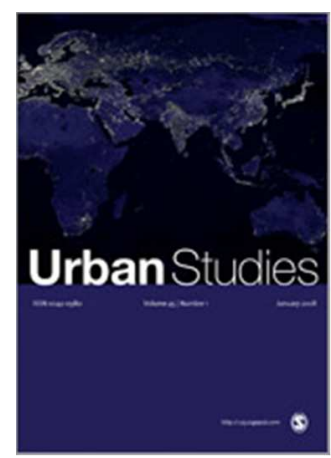

\title{
The Politicisation of Diversity Planning in a Global City: Lessons from London
}

\begin{tabular}{|c|c|}
\hline Journal: & Urban Studies \\
\hline Manuscript ID & CUS-207-15-03.R3 \\
\hline Manuscript Type: & Article \\
\hline $\begin{array}{l}<\mathrm{b}>\text { Discipline: Please select a } \\
\text { keyword from the following list } \\
\text { that best describes the } \\
\text { discipline used in your paper.: }\end{array}$ & Planning \\
\hline $\begin{array}{r}\text { World Region: Please select } \\
\text { the region(s) that best reflect } \\
\text { the focus of your paper. } \\
\text { Names of individual countries, } \\
\text { cities \& economic groupings } \\
\text { should appear in the title } \\
\text { where appropriate.: }\end{array}$ & Western Europe \\
\hline $\begin{array}{l}\text { Major Topic: Please identify up } \\
\text { to two topics that best identify } \\
\text { the subject of your article.: }\end{array}$ & Economic development, Governance \\
\hline $\begin{array}{r}\text { Please supply a further } 5 \\
\text { relevant keywords in the fields } \\
\text { below:: }\end{array}$ & Diversity, Governance, Urban Policy, Planning, Global City \\
\hline
\end{tabular}

SCHOLARONE ${ }^{\prime \prime}$

Manuscripts 


\begin{abstract}
This paper explores the politics of diversity planning in one of Europe's most socially and economically divided and globally-oriented cities, London. The analysis draws on Latour's writings on modes of politicisation to examine the processes and practices that shape contemporary urban governance. It uses the example of diversity planning to examine the 'what' and 'how' of urban politics. It shows that on the one hand diversity is represented in pragmatic, consensual, and celebratory terms. Under prevailing conditions of contemporary global capitalism, the 'what' of diversity has been politicised into an agenda for labour market-building and the attraction of 'talented' individuals and foreign investment. However, at the same time this celebratory rhetoric represents part of a wider effort to deflect political attention away from the socially and economically divisive impacts of global models of economic growth and physical development. There is little discussion of the ways in which planning frameworks, the 'how' of diversity policy, are helping to generate new separations in and beyond the city. Moreover, despite claiming that policy is pragmatic and non-ideological, the paper shows how diversity narratives have become an integral part of broader political projects to orientate the city's economy towards the needs of a relatively small cluster of powerful economic sectors. The paper concludes with reflections on the recent impacts of the vote for Brexit and the election of an openly Muslim London Mayor. It also assesses the broader relevance of a Latourian framework for the analysis of contemporary urban politics.
\end{abstract}

Keywords: Diversity, Governance , Urban Policy, Planning , Global City 


\section{Introduction}

It is widely argued that policy-makers in western cities face growing challenges in catering for the needs of increasingly diverse populations whilst ensuring that broader policy objectives, such as the promotion of economic growth and social stability, continue to be met (see Tasan-Kok, et al., 2013). Writers including the anthropologist Steve Vertovec (2007) claim that some European cities have now become 'superdiverse' centres in which there exists an unprecedented juxtaposition of culturally different groups and populations. Policy-makers are faced with competing and increasingly complex and sometimes contradictory demands to meet 'diverse' needs and expectations. For some, the growing recognition given to 'diversity' requires a radical reframing of state-citizen relations and a new politics that is founded on inclusion and the breakdown of universal welfare entitlements and structure (see Clark and Newman, 2012). For others, the juxtaposition of different forms of diversity in cities and the diverse encounters that they generate, represent an essential component of contemporary urbanism as a way of life (see Delanty, 2012; Fincher and Iveson, 2008). Given its widespread use, and the variety of meanings attributed to it, 'diversity' has thus become something of a chaotic concept but one that is playing an expanded role in shaping urban development agendas, social policy interventions, and planning arrangements.

At the same time, there is a growing conceptual literature in urban studies that argues that the mobilisation of terms such as diversity is indicative of the increasingly post-political nature of urban politics. Governance, it is claimed, is becoming dominated by consensual and seemingly inclusive political framings, such as those associated with diversity or sustainability, that prescribe a superficial sense of inclusion and mutual benefit, whilst disguising the imposition of polarising and increasingly fractious forms of policy intervention (see Wilson and Swyngedouw, 2014). Others, however, writing from an institutionalist perspective have developed very different arguments and call for researchers to examine the 'critical pragmatism' that shapes the everyday politics of planning and development in cities. Research, they claim, should explore the ways in which actors, working in specific contexts, adopt policies and programmes that draw on shared understandings of problems and circumstances and use policy instruments to meet collective, agreed needs (see Forester, 2012; Healey, 2009). Planning for diversity represents one such policy field. At the heart of these different approaches lie fundamental differences over the forms of politicisation that are dominant and the best ways to represent and understand how cities are being governed and in whose interests.

This paper will use the example of development and planning politics in London to demonstrate how the radical or transgressive possibilities present in terms such as diversity are being captured, redefined and re-shaped by powerful interests. The term's political edge, it will show, is being blunted as it is appropriated by specific interests intent on converting it into more 'pragmatic' and 'forward thinking' agendas. It is being used as a technology in itself or a mode of governing and the basis for new governance framings and imaginations. However, the paper goes beyond this and uses the politics of diversity to examine broader processes of politicisation and urban change. It will draw on the work of Bruno Latour and others to examine the multiple character of politicisation that is occurring in contemporary cities and the specific political and material sites and spaces around which agendas and forms of political action are emerging. The paper explores normative framings of politicisation and how they relate to debates over 'diversity'. It will then turn to the London case and adopt Latour's methodology to examine the what and how aspects of diversity politics in the city. In relation to the former, it addresses the specific politics through which dominant meanings of diversity have been given precedence and the ways in which these imaginations have become contested and given meaning. The paper then turns to the latter or the 'how' of diversity politics and explores the institutional and policy mechanisms through which these meanings are being mobilised and converted into contemporary 
planning and development policy agendas in the city. It highlights their fiercely political nature and their outcomes on the form and social character of the built environment.

Collectively it is argued that politicised representations have been used to present the city as a champion of pragmatic, consensual, tolerant and inclusive politics and a force for progressive change, in a European and national context that is becoming increasingly sceptical of the benefits of globalisation. The city is commonly represented by elites as both an object of policy intervention and a corporate-like subject with prescribed needs and capacities of action. We demonstrate how these generic celebratory narratives have evolved into specific vocabularies of labour market-building and policies that are best able to attract 'talented' migrants. Their presence has become a necessary component of an imagined 'London economy' that has separate and particular needs that 'differ' from those of other cities and places within and beyond the UK. We argue that diversity narratives alone have not directly brought about changes to the built environment and/or the types of resurgent urban policy that now exist. What is evident, however, is that the term has evolved to legitimate development discourses that marginalise broader concerns over the impacts of globally-focussed economic and population growth in the city and direct political attention towards more consensual narratives, such as 'cultural vibrancy' and the 'positive contributions' that in-migrants and investors make to collective economic well-being. As with similar governmental constructs, such as sustainability and resilience, diversity has taken on a chaotic form and been used to justify a variety of ambiguous, and at times contradictory, social and economic policy rationalities.

\section{Processes of Politicisation and the Governance of Urban Diversity}

The Politicisation of Urban Governance

A growing body of writing on urban politics has focused on the ways in which neo-liberal governance technologies and practices are seeking to de-politicise policy-making and remove contentious debates over policy priorities and demands out of the realms of public discussion (see Crouch, 2011; Swyngedouw, 2015). Drawing on the work of Rancière (2006) and others there has been a focus on the tactics and strategies of governance that now dominate policy-making in western countries and the growth of so-called non-ideological, pragmatic, and managerial agendas. For Swyngedouw (2009) politics has entered a new era in which there is an emphasis on illusions of consensus and the rise of a win-win politics in which it is assumed that policy interventions are focused on meeting shared and collaborative 'agreed' needs in the most efficient and effective ways possible (see also Kenis and Mathijs, 2014; MacDonald, 2015). Much of the writing on post-politics draws on Republican traditions in which politics is equated with (class-based) demands and the mechanisms of representation in and through which (in)equalities of access to political processes are framed. The emphasis has been on how access to political processes and engagements has been increasingly 'closed-down', with public discussions relegated to limited concerns over best practices and efficient forms of policy implementation. Research has shed light on the use of technologies and selective vocabularies of governance as mechanisms to limit political engagement and the articulation of 'alternative' views that might encourage dissensus. It is an approach that chimes with contemporary urban policy trends that appear to show the growing power of capitalist and developmental interests to shape the politics of urban development (see Metzger et al., 2014).

However, this shift towards post-politics, if it exists, represents only one mode of contemporary politicisation and needs to be situated within broader and more complex social and political processes of change. Recent work in Science and Technology Studies has been particularly insightful in drawing attention to the range of processes through which particular issues or terms take on political forms. 
Much of its influence on urban studies has related to a focus on assemblages and actor-networks, but some of its more valuable, but less analysed, insights relate to understandings of political processes and the ways in which specific objects of governance are mobilized and converted into subjects of and for political debate. For Latour (2007), sites of politicisation are not only to be found in formal institutional structures and political processes. Politics, instead, needs to be understood as an object-centred exercise with issues becoming constituted through public concern and action. As he claims 'the key move is to make all definitions of politics turn around the issues instead of having the issues enter into a ready-made political sphere to be dealt with' (p.5). This requires the development of a methodology and ways of thinking that explore how we might be able to 'qualify different moments in the trajectory of an issue with different meanings of the adjective political' (p.6). Or as De Vries' (2007) argues, rather than thinking about democratic politics 'in terms of procedures that regulate the contributions of subjects', a broader understanding of politicisation should 'address the question of how in a democracy political objects can be constituted' (p.807). This means that the same public issue or set of issues, such as those surrounding 'diversity' planning, may be constituted by very different or even ambiguous and contradictory meanings depending on how the term becomes politicized and converted into a set of policy objects and frames.

Latour structures his discussion of politicisation through five types of issue formation and understanding (see Figure 1). The first relates to the new associations that are created between actors and how these shape policy imaginations and frameworks. Drawing on a broad range of work in STS, Latour claims that these relationships force subjects to re-define their own ways of viewing the world and re-think their positionality vis-à-vis other subjects (see also Urry, 2007). There are strong echoes of this form of politicisation in contemporary writings on diversity and contemporary urban identities. These emerge, it is claimed, through processes of interaction, engagement and encounter and can take on a range of forms from hostility and distrust to tolerance and mutual learning, all of which propagate specific types of politicisation and political mobilisation. In Delanty's (2012) terms diversity becomes an 'empirically grounded normativity' in which 'universalistic orientations emerge from a critical engagement with one's situation, the particular, the here and now in so far as this is a situation involving a relation with others' (p.336).

\section{INSERT FIGURE 1 HERE}

A second mode of politicisation, and one that has attracted growing interest in planning and urban political theory, is taken directly from the writings of early $20^{\text {th }}$ Century pragmatist writers, such as philosophers John Dewey and Walter Lippman. Pragmatist modes of politicisation focus on the ways in which specific issues and objects of political attention emerge through the constitution of concerned and unsettled publics and how these become converted into practically-oriented types of political action. It is an approach that has become increasingly influential in planning theory and acts as a counter-weight to more critical perspectives in post-political and/or political economy writings. Authors such as Forester (2012) and Healey $(2009$; 2012), for instance, claim that a form of 'critical pragmatism' shapes contemporary urban political and planning debates in European cities, framed by 'shared meanings' and understandings of the collective problems to be addressed, such as economic growth or sustainability, and the possible paths of action that are open to actors (see also Rorty, 2008). For pragmatists, politicisation emerges through the activation of publics and groups of interests who then engage with issues and seek to bring about change (see Marres, 2007). The emphasis is on how political debates and processes can be used to generate more effective and 'realistic' responses to perceived problems with due recognition of given circumstances and the incremental nature of solutions.

A third form of politicisation is that of government bodies seeking to act with sovereign power, or how they use the institutional machinery of government and judicial-technical forms of power to tackle 
defined problems. Governments seek legitimation for their actions and call on their experts and technocrats to deliver policy programmes. This often takes the form of Public Management programmes and the implementation of bureaucratic-technocratic procedures of governance. Too often, studies of urban politics have become over-focussed on such policy arrangements and whilst they play an essential role in shaping political conflicts and outcomes, they are also limited by recurring implementation deficits, contradictory logics and unintended consequences (see Giddens, 2009). And as Le Galès (2012) notes what is not formally governed in cities is often as important to urban politics as what is governed. Informal networks and relations, sometimes broadening into illegalities, can have a powerful effect on the form and character of urban politics and the relationships between citizens, communities, and state bodies.

A fourth type of politicisation involves the use of deliberative technologies and institutions to propagate collaborative public engagement and co-produce policy outcomes. As will be discussed below, in relation to debates over inclusion and diversity, idealistic conceptions of such processes have driven policymaking frameworks and reforms since the early 1990s. And finally, Latour highlights a fifth stage, that of apolitical forms of governmentality in which 'an issue has stopped being political, at least for a while, because it has become part of the daily routine of administration and management' (p.103). He does not argue that the politicised character of such topics have disappeared or no longer exist but that 'on the surface [they] appear to be absolutely apolitical, and yet in their silent ordinary fully routinised ways are perversely the most important aspects of what We mean by living together' (ibid.). There are strong echoes of this de-politicisation in pragmatist accounts that present urban politics as a series of issue-byissue problems to be resolved through the implementation of specific, practical and 'common sense' solutions.

The strength of such an approach is that it provides a strong methodological foundation for the exploration of urban politics and understandings of politicisation in the city. The role of research is to systematically explore and address the wider questions of 'what are the things politics should turn around and how is it going to turn around those things' (Latour, 2007: p.9). The implications of this way of thinking about urban politics are profound. It challenges the taken-for-granted assumptions in political science about where political power is located and what the boundaries of the political and non-political consist of (Marres, 2007: p.763). In Purcell's (2013) terms, too much writing on democratic processes elides democracy unproblematically with the deliberations and actions of state institutions. This, however, 'is a form of oligarchy that sets severe limits on democracy and insists that anything beyond those limits is impossible' (p.26). Focussing on the 'what' and 'how' of politics opens up a series of important questions and insights into the ways in which political terms, such as diversity, become converted into political projects and programmes and how this takes places. It points to the specific moments and spaces in the city in which there are sites of conflict or consensus over the (political) meanings ascribed to such terms and their material and discursive effects. It enables research on abstract terms to take on more concrete forms and move beyond relatively simple discourse or content analysis. The framework is synchronic, rather than sequential in that it is possible for multiple forms of politicisation to co-exist at a particular moment or around a particular issue. An exploration of the 'what' and 'how' also enables a more critical discussion of the links between discursive framings and actions/practices. For instance, it may be politically expedient for policy framings to present themselves as non-political, pragmatic, or technical to reduce the opportunities for conflict, whilst simultaneously promoting programmes of action that have divisive consequences and/or empower elite groups and organisations. Deliberations over the what and how of diversity politics provide a powerful example of these processes in action and it is to its broader politicisation that the discussion now turns.

Politicising Diversity

http://mc.manuscriptcentral.com5cus Ruth.Harkin@glasgow.ac.uk 
The widespread growth of the term diversity in planning and policy-making agendas reflects the coemergence of multiple forms of politicisation, particularly when it takes on concrete forms in specific places and urban contexts. It has become a rather 'chaotic concept' (c.f Sayer, 1997), prone to multiple interpretations and deployed to meet a range of diverse, and sometimes contradictory agendas. Debates over diversity's ascribed meanings have been fuelled by broader tensions between those who present it primarily as a 'cultural/semiotic' construct, concerned with the presence of multiple identities and cultural rights, and others who see it in 'economic/material' terms, or through the distinctions between collective class interests (see Ahmed, 2008; Fincher and Iveson, 2008). Whilst this simple binary distinction is sometimes over-drawn in critical writings on diversity (see in particular Bourdieu and Wacquant, 2006), it has helped to shape what aspects of the term have been politicised in urban contexts and how.

For Keith (2005) cities act as the primary mediators of global processes and the sites through which debates over the politicisation of diversity are enacted. Whilst transnational globalisation has created new sites of cultural and social diversity, this diversity in turn 'brings with it a debate about the contesting of the social and political settlement of the city' (p.4). In many cases, Keith argues, cities are acting as crucibles of change, or the principle sites through which new forms of cosmopolitan and transnational connections, chronologies, and spatialities are emerging. Rapidly changing cultural forms mean that 'the city is [becoming] pluralised at a rate of change that can defy academic categorisation and generalisation' (p.5). The same is also true for the imaginations and representational frameworks that shape policymaking and dominant conceptions of who is present and absent in a defined governmental space (such as the city or neighbourhood) at any one time. It is a process in which vocabularies and technologies of description are used to create simplifications and narratives of diversity that then become embedded in wider political projects of action (see Ahonen et al., 2014). These political projects draw on selective narratives and are brought together by powerful elites which influence, directly or indirectly, the boundaries of political debate. As Keith (2005) argues, different forms of politicisation in turn create representations 'through which the analytical world is made visible and rendered comprehensible as an object of study' and that these, in turn, 'are constitutive of the subject[s]' that live in cities (p.28).

The potentially contentious nature of diversity planning and politics sits uneasily with(in) the consensual language of contemporary politics with its sobriquets of partnership, co-production, and community. In many cities there has been a tendency to convert the term into an instrumentalist commodity, that is used to promote the 'contributions' that diversity makes to economic competitiveness, creativity, cultural vibrancy, and the operation of key welfare services. The commodification of diversity and its remaking into a socio-cultural asset requires the mobilisation of a particular form of political discourse in which it is imagined that there exists in cities an 'automatic consensus of painless adjustment between the collective negotiation of power and the individual negotiation of pleasures within mass democratic society' (Rancière , 2006: pp.110-111). By focussing on what are perceived to be 'safe' political terrains and discourses that will help to sustain the existing ordering of policy, a consensual framing of diversity 'functions to take the heat out of conflicts and to divest values' (ibid.). Diversity in some places has therefore been deployed as, what Radaelli (1999) terms, a 'political anaesthetic', or an agenda that has 'the potential for eliminating conflict' (p.16).

During the 1990s and 2000s diversity has primarily been incorporated into three types of political project in European and North American cities: (i) creativity and economic development strategies; (ii) cultural projects to ensure social 'cohesion' or order; and (iii) welfare reform programmes and the disintegration of universal entitlements. Each has been underpinned by specific forms of politicisation over 'what' aspects of diversity should be recognised, mapped, and promoted and 'how' these should be converted into agendas and programmes of government.

(i) Creativity and economic development agendas 
It has become increasingly common for urban policy-makers to draw on new vocabularies that politicise diversity through the presentation of 'iconic subject positions [which] become reified in social policy and catered for in city plans' (Keith, 2005: p.28). For example, many cities present themselves as 'global' and 'diverse' in an attempt to meet wider policy objectives, such as the attraction of Foreign Direct Investment or to create a more positive external image to attract one off sporting or cultural events. They may establish a cast-list of iconic subjects such as 'talented' or 'creative' workers or draw on specific metaphors of spatial patterning (such as that of a mosaic) to justify and legitimate their policy interventions, some of which have been divisive in social and spatial terms (see Atkinson and Easthope, 2009; Fincher and Iveson, 2008). Selective visions of diversity became elided with broader urban policy orthodoxies and political projects, especially those that promoted the growing power and significance of resurgent urban economies and their populations (see Scott and Storper, 2015). As Nathan (2015) shows, a diversity of workers and 'tolerant' and open forms of urban politics are increasingly presented as necessary ingredients for contemporary forms of urban growth as policy agendas echo the economic orthodoxies set out by authors of the so-called New Economic Geography such as Richard Florida (2014) and Ed Glaeser (2010). The World Economic Forum (2015) and other development bodies even go as far as to highlight the importance of 'diversity dividends' in cities that are more diverse and possess a broader range of creative and entrepreneurial workers (see Syrett and Sepulveda, 2012)․․

Such proclamations provide a set of clear prescriptions for urban and social policy and see higher levels of in-migration and socio-cultural diversity as a precondition for economic advantage. Despite a range of evidence showing that economic growth is a consequence of a much broader range of dynamics and influences (see Martin, 2015), and that the types of growth supported by enhanced diversity generates employment that can threaten terms and conditions for poorer workers, the political and economic arguments for the promotion of 'more diversity' have become a powerful and influential orthodoxy, particularly amongst policy-makers in cities. In establishing policy narratives that focus on the perceived material benefits of diversity for creativity and economic competitiveness, there has been a tendency towards pragmatic forms of politicisation that downplay and de-politicise some of the possible ambiguities and conflicts that might emerge over, for example, the differential impacts of development on different groups. It is a form of politicisation that simultaneously incorporates public management approaches and an explicit commitment to forms of 'pragmatism' in making the most of the possibilities and potentialities of diversity.

\section{(ii) Cultural projects to ensure social 'cohesion' or order}

The social policy field in which there have been, perhaps, the most contentious forms of politicisation over diversity has been over its effects on social order and social movements. In many contexts, diversity narratives have taken on a culturally-focused character in which the issues surrounding difference and the expression of community/citizen rights have been to the fore. For writers such as Vertovec $(2007 ; 2012)$ many European cities have entered a new era characterized by 'super-diversity' in which there are unprecedented juxtapositions of different socio-cultural groups, particularly in cities. This, in turn, has generated new types of social imaginary in which civil society and state bodies now actively recognise the presence of diversity and see it as the basis for the formation of new political rights and agendas (see also Turner, 2009). At the same time, the growth of civil rights and social movements, particularly in the United States, has fuelled forms of politicization that call for greater equality for different groups and a broader politics of recognition (see Bourdieu and Wacquant, 2009). Such imaginaries have formed an

\footnotetext{
${ }^{1}$ World business leaders in Davos in 2015 lauded the 'diversity dividends' that accrue from diverse labour markets and the wider pool of skills and talent that they bring.
} 
important part of how diversity has become politicised in urban politics and development strategies and is seen as a uniting and inclusive set of discourses.

The focus on the relationships between growing diversity and identity politics has spawned a vast literature on urban social change and living with difference. Recent writings in urban sociology and planning have explored broader questions of commonplace diversity or the ways in which everyday settings such as streets and coffee shops act as places of encounter and exchange (see Beebeejaun, 2012; Hall, 2012; Neal et al., 2012; Wessendorf, 2014). There are also a plethora of institutional studies that focus on the recruitment practices of organisations and the extent to which their activities and values shape the lives of different groups (see Ahmed, 2012; Swan, 2008). The political implications of such work often remain implicit, rather than explicit. The focus is on propagating new forms of recognition and institutional working that is less prejudiced and/or biased against certain groups. It calls for planning arrangements to give due recognition to the importance of encounters in the city and the provision of spaces in which encounters can take place.

And yet as Clarke and Newman (2012) note, 'it is a strange intellectual choice to abstract increasing ethnic diversity from other social changes taking place in Northern societies over the past few decades' (p.96). Its prevalence has led a number of writers to challenge the ostensibly progressive cultural uses of the term diversity itself and the forms of politicisation that have been associated with them. For some, excessive social and cultural diversity in the EU is generating a new crisis of social solidarity (see Goodhart, 2004; Žižek, 2014). Too often, Keith notes, descriptions of diverse cities act 'less a descriptive vocabulary than an ethical project' (p.39) or a normative view of how cities are and what good forms of city living should consist of. The European Elections of 2014 indicate a broader shift in popular discontent and a rejection of the openly pluralist, cosmopolitan politics of the 1990s and 2000s (see The New Statesman, 2014). Antiimmigrant and diversity movements have emerged in many countries that openly reject models of diversity, although the specific political messages they convey vary considerably. Even mainstream political leaders such as Angela Merkel claim that the period of pluralist and multi-cultural politics has 'utterly failed' (BBC News, 2010) and that social policy should focus more on integration in the midst of diverse societies.

Others, more focused on material and political economy arguments, are also fiercely critical of the culturally-focused character of recent politicisations of the term. Michaels (2010), for instance, powerfully asserts that the focus on diversity as a force for a new cultural politics of recognition has helped to legitimate a wider shift towards exploitative and polarising forms of capitalism. He argues that not only have 'the successes of the struggle against discrimination' embedded in positive diversity narratives 'failed to alleviate inequality, but that they have been compatible with a radical expansion of it' (2010: p.3)2. Or as Žižek (2011) notes from a political economy perspective, policy-makers have used diversity narratives, along with others (such as cosmopolitanism or globalisation), to seek to overcome the fundamental ambiguities in contemporary social and economic policies in which divisive and alienating capitalist growth is simultaneously promoted along with inclusive discourses of democratisation, tolerance, and empowerment. Rather than being progressive, such narratives may, therefore, act as catalysts triggering forms of politicisation founded on 'the production and self-perpetuation of difference, and the efforts to build a community around it' (Bauman, 2003: p.77). They may stand in the way of the formation of broader political alliances and movements and weaken opposition to policy interventions that are generating inequalities. More relational and multi-layered understandings of diversity become simplified,

\footnotetext{
2 Material inequalities have expanded in almost every western society despite decades of diversity-based public policy. In countries such as the UK 1\% of the population now owns more collective wealth than the bottom 55\% (The Guardian, 2014).
} 
with the consequence that 'progressive' economic reforms that seem to promote greater equality, paradoxically protect and reinforce existing socio-economic differences (see Bridge, 2005).

\section{(iii) Welfare reform programmes and the disintegration of universal entitlements}

Across Europe, even in countries with strong traditions of centralized welfare, the presence of greater 'diversity' has become elided with a form of politicization that sees the end of universal entitlements as inevitable. Diversity has become inter-twinned with neo-liberal programmes that promote the 'end of welfare' as the 'logical consequence' of the assumption that 'migration is making contemporary European societies more diverse; and diversity undermines the sentiments of social solidarity that have sustained welfare states' (Clarke and Newman, 2012: p.94; see also Antonnen, et al., 2012). Governments on the left and right increasingly argue that state bodies have little option but to make themselves more responsive to the changing needs of diverse modern populations and embark on reform programmes that end 'universal' forms of provision and make welfare more selective and 'personalised' in response to changing needs (see for example Giddens, 2009). It is a form of politicization that is focused on the mapping and making visible of demographic diversity and the conversion of these new realities into pragmatic and technical modes of reform and policy invention. It is being presented as a progressive and realistic 'pragmatic' approach that will create more responsive welfare systems and help to de-politicise some fundamental difficulties and tensions emerging across western cities and societies.

In the remainder of the paper the discussion now turns to the example of London and the different forms of politicisation of diversity that are evident in the development politics and strategic planning of the city. The findings draw on an on-going research project that examines the ideologies and meanings of the term diversity in public policy debates and its impact on urban political agendas and changes in the built environment. It set out to explore how the inherent tensions and ambiguities of the term have been 'resolved' (at least temporarily) in the formation of specific political projects and through material policy interventions in the built environment, urban planning policies, and economic development strategies. It looked for sites of 'conflict' in and through which ideological framings of diversity have been mobilised and managed and some of the practical and concrete policy areas in which forms of elision and resolution have evolved. Collectively, the paper argues that the dominant mode of politicisation is a formal conservative pragmatism, very different to the 'critical' pragmatism as normatively outlined by writers such as Healey (2009) and Forrester (2012). What is evident is a framing of diversity through simultaneous modes of politicisation as both a policy object, to be governed and managed for wider policy aims, and a policy subject whose presence can help produce core policy outcomes.

Our analysis is taken from 18 interviews conducted between July and December 2014 with policy-makers, planners, government officials, business organisations and civil society representatives in London and the systematic collection and analysis of policy documents connected to planning and urban development politics. They were collected, sorted, and analysed by theme and we have drawn on their analysis selectively in the discussion that follows to triangulate the views of interviewees and highlight some of the core narratives of diversity that frame policy discourses. In short, we focussed on the 'what' and 'how' of diversity politics, or what aspects of diversity have been mobilised and incorporated into policy and how this has been done, and with what effects. It is important to note that the research was conducted before the election in May 2016 of Sadiq Khan, the city's first openly Muslim Mayor. The UK's vote to leave the European Union in June 2016 and a string of terror attacks by so-called Islamist groups across the EU, have all contributed to more intense forms of politicisation in relation to diversity. Their implications will be discussed in the conclusions.

\section{Narratives of Diversity and the Governance of London}


Dominant narratives and representations of London curate it as one of the most diverse cities in Europe. It has been described as 'the world within a city' (Greater London Authority [GLA], 2005) and a place of 'super-diversity' credited to be the most 'cosmopolitan place on Earth' (Vertovec, 2007). The 2011 census revealed that out of a total population of 8.17 million, 2.6 million (31\%) were born outside of the UK. Moreover, $55 \%$ of respondents defined themselves as other than White British (including both residents who hold a foreign passport and British citizens from Black and Minority Ethnic backgrounds). This proportion has risen from $31 \%$ in 1991 . The city is home to $41 \%$ of all non-White British residents of England and Wales, to $37 \%$ of all residents born outside the UK and to $24 \%$ of all non-UK nationals ${ }^{3}$. Alongside this ethnic and cultural diversity, socio-economic inequalities have also expanded relentlessly, with a growing divergence in life chances, opportunities, and incomes. Dorling (2011) shows that the richest $10 \%$ of London's residents now have 273 times the income and assets of the poorest $10 \%$, a figure that is higher than at any time since the Nineteenth Century. As Douglass (2012) argues, this is creating new forms of 'enclave urbanism' in which powerful global elites live in exclusive and increasingly gated and gentrified parts of the city (see Imrie and Lees, 2014). All of this makes planning for diversity a particularly challenging task. Despite London's overall economic vitality, $28 \%$ of the population live in households that are in poverty (after housing costs) ${ }^{4}$ compared with the UK figure of $22 \%$, covering more than two million Londoners.

The national policy context within which diversity narratives are being forged has also become increasingly hostile to the types of migrant-led diversity found in London. English policy has followed a broader European trend in becoming critical of multiculturalism and presenting diversity as a long-term threat to social cohesion. This has partly been fuelled by increased immigration. Migration to the UK as a whole has grown significantly in the last decade with the number of East Europeans, for example, totalling 895,000 in 2015 (The Guardian, 2015). It has become a major political issue for policy-makers at all levels and for all political parties with the post-2010 Coalition and subsequent Conservative governments setting out new cultural policies that establish 'common ground... [and] a clear sense of shared aspirations and values, which focuses on what we have in common rather than our differences' (DCLG, 2012: p.5). The narrative has become one of 'integration' around core so-called British values 'underpinned both by opportunities to succeed and a strong sense of personal and social responsibility to the society which has made success possible' (Ibid, p.4). Rather than seeing integration as something that can be planned for and implemented by public actors, the emphasis is on changing the subjectivities of individuals and communities and their dayto-day practices. There is relatively little discussion or reference to the urban-centred character of diversity in England or the ways in which transnational and local identities are being remade in the everyday life-worlds found in urban communities. The focus instead, is on abstract understandings of non-relational collective identities, based around nation-state centred outlooks.

It is within this wider context that the politicisation of diversity narratives in London has evolved. In contrast to other English cities, the presence of an elected Mayor and the Greater London Authority provide some strategic direction to the mobilisation of different priorities and a focus for locally-oriented

\footnotetext{
3 A self-identifying question on 'ethnic group membership' was introduced in the census for England and Wales in 1991. For an overview of how ethnicity and identity is measured in the UK, see http://www.ons.gov.uk/ons/rel/census/2011census/key-statistics-for-local-authorities-in-england-and-wales/rpt-ethnicity.html\#tab-Measuring-ethnicity-. In the 2011 Census 18 'ethnic' categories were defined. Additionally, the 2011 Census included questions on religious affiliation, language spoken at home, and national identity. To define international migrants, the census used country of birth and passport held.

${ }^{4}$ In the UK the poverty threshold for a household is defined as an income after tax which is below $60 \%$ of the average (median) household income for that year. It can be measured before or after housing costs.
} 
policy deliberations ${ }^{5}$. Formal governance arrangements are two-tiered, with a Mayor, a London Assembly and 33 sub-metropolitan Boroughs (see Kesten et al., 2014). Alongside this London's publics are constituted by such a high level of diversity that the meanings and policy agendas inscribed in the term carry significant weight and have become fiercely politicised.

The following sections now explore two prevailing forms of politicisation that are emerging and how the term has become situated within planning and economic development frameworks across the city. It assesses the 'what' and 'how' of diversity politics and shows how different aspects and imaginings of diversity are being deployed within a broader collection of powerful political narratives to legitimate a complex set of competing policy rationalities. There are deep ambiguities within such agendas between, on the one hand, the promotion of London's global model of economic growth, in which diversity plays a key role, and on the other a fear that the speed and character of growth is fuelling marginalisation and new divisions between citizens and groups. The first section examines the rise of dominant politicisations, or what aspects of diversity are privileged. It looks at the new vocabularies and representations that are being deployed that re-imagine the city as a commodified and integrated economic and social unit and some of the absences within these narratives. The second section then turns to the how of diversity politics, or the broader implementation of diversity projects across the city. The evidence highlights their growing fusion with those of assimilation, welfare reform, and the legitimation of urban development projects that generate heightened inequality and spatial polarisation. It also explores some of the themes that policy-makers are reluctant to discuss under dominant modes of pragmatic politicisation, such as growing inequalities in the city between different groups and an emerging crisis of social reproduction.

\section{Pragmatic Instrumentalism, Commodification and the 'What' of London's Diversity Politics}

The dominant politicisation of diversity found in London's formal policy-making frameworks are viewed, by respondents, as being pragmatic and therefore 'different' to those found in increasingly hostile national policy discourses. They are best summed up by the perspective of one interviewee who argued that the general approach of government bodies was to "make the most of diversity" for the collective good of the city. This is to be achieved through the establishment of specific descriptions of the city and drawing on these to establish policy prescriptions and strategies. The Mayor's London Plan defines diversity as both a set of outlooks and:

'the differences in the values, attitudes, cultural perspective, beliefs, ethnic background, sexuality, skills, knowledge and life experiences of each individual in any group of people constitute the diversity of that group. This term refers to differences between people and is used to higblight individual need' (GLA, 2011: Annex 5, Glossary).

Policy, it is claimed, needs to strike a balance between the collective needs of diverse individual citizens and their communities. It is stated that, 'the Mayor is committed to securing a more inclusive London which recognizes shared values as well as the distinct needs of the capital's different groups and communities, particularly the most vulnerable and disadvantaged (paragraph 3.2). This tension between shared values and distinct needs is to be overcome through the combined efforts of the Mayor's executive departments, such as the GLA working in partnerships with other state, private sector, and NGO bodies.

Interviewees stressed that this approach was 'non-political' and was being designed not only to accommodate the expansion of a future London but also to provide benefits for the rest of the UK. It is based on managerialist modes of politicisation and corporate collectivity in which London's businesses, residents, and workers are presented as a bounded, collective whole and distinct from other places who

${ }^{5}$ Although at the time of writing, new plans to create new stronger Mayors in other English cities such as Manchester have been announced. 
are presented as potential and actual competitors. Diversity is reified into a positive asset that fosters both competitiveness and greater social cohesion as though the two are compatible if only the right forms of recognition are built into policy narratives. It becomes what Keith (2005) terms a 'Whiggish' representation of a city in which there is a simple and progressive narrative of soft assimilation and cohesiveness.

And yet, this pragmatic approach has primarily presented diversity as an essential component of the city's economic competitiveness. In terms that echo those of authors such as Glaeser (2010) and Florida (2014) London is presented as a prime example of a resurgent urbanism founded on the skills and entrepreneurialism of creative workers. There is an explicit emphasis on turning the city into, what one respondent termed, a "global talent bub" with an available pool of skilled workers, the presence of a probusiness growth politics, and an expansion in the availability of housing for key workers. The former London Mayor has even gone as far as to call for a new Visa Category for those with 'Exceptional Talent' to be allowed access to London in order to provide a 'clear message to the elite of Silicon Valley or the fashionistas of Beijing that London is the place they should come to develop ideas, building new businesses and be part of an 'epicentre' for global talent' (Johnson ${ }^{6}$, quoted in Warrell and Pickford, 2013: p.1). It is an agenda that is powerfully supported by big business voices in the city, with the employers' organisation London First (2015) for example, calling for policy to 'manage migration effectively to ensure London's position as a world leader for talent is maintained and strengthened' (p.1). Similar comments were made by interviewees from London's business groups who openly talked of a "premium of people" in the city. The narrative is one of selective migration and labour-market building that extracts maximum benefit from the city's socio-economic diversity. In the words of one GLA representative, the emphasis of such narratives have been focussed on attracting the right types of migrants and "looking at how to keep London competitive and attractive to international students, or high skilled migrants... as an enabler of jobs and growth".

For city planners and managers the presence of diversity can also be converted into a marketable commodity for London's place-marketing activities. The London Olympics 2012 acted as a precursor to place-branding programmes as it demonstrated how diversity could be re-packaged and re-presented as a positive marketing tool and a technology of social description (see Silk, 2011; Winter, 2013). The image of the diverse city has not been 'hidden' as some urban entrepreneurial writers envisaged would happen as cities became more focussed on promoting their conformity to the needs of inward investors (see Hall and Hubbard, 1996). The GLA, the Mayor and other London bodies have, instead, sought to do the opposite; to turn it into a commodity that can be used to act as a tool for economic development strategies and programmes.

These positive and inclusive messages have found fertile ground as elite interests within the city seek to both influence its planning and its broader marketing. Organisations such as London\&Partners, a publicprivate body that promotes London to high-level international investors, curate the city as one of thriving diversity and that this in turn gives it a critical edge in attracting inward investment and the 'right sorts' of in-migration?. The organisation presents 'diversity' as a utilitarian construct and as a factor that helps the city to stand out as an investment space when compared to its rivals; 'London offers Europe's best and most diverse workforce. Among more than $4 \mathrm{~m}$ workers you'll find 230 languages, tech specialists, 400,000 creatives and some of the world's best professional services partners' (p.1). London is therefore seen as a coherent, bounded space in

\footnotetext{
${ }^{6}$ The former Mayor, Boris Johnson, is a Conservative Party politician who was elected in 2008 and re-elected in 2012.

${ }^{7}$ London \& Partners's website defines the organisation as 'the Mayor's official promotional organisation showcasing London as the best city to visit, invest and study in. It is a not-for-profit company limited by guarantee, funded by the Mayor of London and commercial partners' (see: https://www.london.gov.uk/priorities/businesseconomy/championing-london/london-partners)
} 
which distinctive agendas and diversity policies can emerge because of its economic vitality and the global orientation of its most successful economic sectors, such as finance, media, and the business advice industries. Strategies such as London Enriched, typify the instrumentalist character of these city-wide narratives in arguing that a managed policy of migration is 'essential to maximising its [diversity's] benefits and supporting integration vital to minimising its costs.

Despite being presented as 'non-political', these vocabularies establish new forms of potential division and commodification. This is exemplified in the Mayor's 2020 Vision that explicitly states that the city would benefit from an 'immigration policy to attract the brightest and the best to London but keep out those who have no intention of making a contribution' (Johnson, 2012: p.51). Thus claims that London's approach differs markedly from the UK government's integrationist agendas are only partially true. Representations of 'good' and 'bad' migration and the idea that policy should encourage only 'willing' migrants to come to the city for whom there is a specific 'need'. It is an approach best summed up by what one senior central government respondent, emphasized as:

"the financial benefits to the city, the fact that it gives the city kudos, the fact that the city's not like any other city, and he [the Mayor] realizes equality and diversity is actually something that you can sell the city on... he [the Mayor] knows that bis constituency is a diverse community and be will engage with local people".

The negative impacts of globally-focussed neo-liberal policy are put to one side in the desire to curate the city as an attractive economic space. Diversity thus becomes promoted as a latent factor of production that can boost the competitiveness of existing businesses and the social mobility of poorer residents.

At the same time there is little recognition given to some of the wider structural barriers that exist that limit the opportunities for many of London's citizens to improve their welfare and/or life chances. By emphasising consensual, pragmatic, and 'realistic' narratives, the mechanisms through which policy (non)interventions undermine diversity policy objectives remain firmly off political agendas. To support the needs of any particular group involves the imposition of political choices as others will directly lose out in terms of jobs, incomes, or changes to the urban form. The mechansisms through which redistribution and equality will be delivered remain vague and relegated to a concern with the role of a vibrant and exciting urban environment in aspiration-building, boosting social capital, and enhancing individual obligations and responsibilities.

This individualistic approach is closely connected to the consensus-based pragmatism of policy narratives. Broader questions concerning discrimination and intolerance in the city are put to one side or incorporated into a language of individual aspiration and wider tolerance. In the words of one NGO interviewee, the emergence of this individualistic politics is that,

$$
\begin{aligned}
& \text {...it removes the ability to name the problem, so unless you are prepared to identify patterns of } \\
& \text { racial injustice and name them as such it gets very difficult to address them because we're not really } \\
& \text { sure what we're talking about, hence my concern about the slippage of language into diversity. }
\end{aligned}
$$

Others, such as Trade Unionists, were also very cautious about the political implications of using the term as "it was so soft and ill-defined that it was a deliberate attempt to blur campaigns and struggle for equalities agendas". For those talented individuals who are seen to be making a 'contribution' to London's wider competitiveness, the narratives are entirely positive and tolerant in form. However, as one representative of a migrant support NGO noted in interview, 
people who are coming to work in industries like food processing, or construction, hotels, catering, social care and low skilled work, get a far less sympathetic hearing... as things have developed it has become a lot clearer to us exactly what the agendas are.

The class divisions inherent in the ways in which equality and diversity in London is framed are reflected in what one respondent termed the emergence of "diversity as a luxury product" that had become the preserve of elite groups and other 'realistic' bodies such as big business. As one NGO noted,

the danger is that diversity can easily be presented as being part of a middle class agenda, about the number of ethnic restaurants on your local bigh street... it's about image, it's about London being up there with the top two or three cities in the world - it may be an exciting, vibrant place but then there's a complete disconnect between that and a sense of what it's like living in communities which have been buffeted around and are feeling marginalised within that dynamic economy.

This form of simplification, it was widely claimed by community-based respondents and NGOs, created a dangerous mismatch between formal policy and the recognition that contentious political decisions had to be made. One activist noted for instance that,

there is a danger that it's [diversity] a badge that a city that's aspiring to be global takes on and it trades in... but when it comes to following it through to what it really means, putting together a city of eight million people and what's needed to make that work, then nobody's got any ideas on that, nobody knows what the true nature of the problem is.

This section has examined the core elements contained in the 'what' of diversity, or those aspects of the city that diversity narratives and frames of reference focus on and seek to define. It has highlighted the types of politicisation that underpin these framings and some of the political processes involved in their construction and mobilisation. Some of the key points of contestation and politicisation embedded in these curations of London are reflected in urban policy interventions in the city and it is to these, as examples of the 'how' of urban diversity policy, that the paper now turns.

\section{The How of Diversity Politics in London and the Propagation of Division}

Social and urban policy narratives of diversity are forming an important part of a wider neo-liberal politics in which welfare state support and expectations of security are being withdrawn. This fuels ambiguities in policy in which commodified diversity is presented as an asset to boost growth and investment at the same time as such investments are having major social and economic impacts on citizens and on spatial patterns of diversity. The GLA ostensibly promotes Equal Life Chances for All, a strategy that aims to:

'to use traditional forms of social research and innovative digital engagement and social media monitoring to establish how Londoners see the world around them and respond to policy proposal' (pp.30-31).

London Boroughs and public bodies are required to have baseline data available for planning purposes to both facilitate the effective management of policy and to limit the potential for legal challenges to their decisions. There has, therefore, been an attempt to make diversity 'visible' and to construe it as both a policy problem and an opportunity. In the Mayor's terms, 'we have now developed a more holistic approach to minimising disadvantage, one which brings Londoners together rather than separating and pigeon-holing people as had been done in the past' (Johnson, 2013: p. 1). The role of planning policy is to manage its wider effects on the city's order and the competitiveness of some of its core economic 
sectors. Managerial representations in the form of strategies, targets, statistics, and plans are used to try and bring some cohesiveness to policy and to demonstrate that some of the potential problems associated with diversity are manageable and are being tackled through specific forms of intervention. The GLA alone has published over 30 strategies between 2008 and 2014.

However, at the same time representations of 'diversity' are being elided with the neo-liberal welfare expectation that policy will no longer look to accommodate differences but should instead seek to 'mainstream equalities' and support individuals by increasing opportunities for all. This is reflected in a shift towards a more revisionist and integrationist set of approaches in which the proclaimed objective is that, as one GLA interviewee noted, “we don't target communities" but instead think more about how policies treat individual citizens as 'equals'. The consequence of this is that when developing social policy narratives, and in marked contrast to the vocabularies of place-marketing, "we never talk about diversity as immigration, or ethnicity". The emphasis, instead, is on using equalities legislation and voluntary programmes to encourage employers and other actors to think about their own practices and to put in place pro-diversity programmes, with relatively little direct state compulsion or regulation. Such approaches reflect and reproduce what Swan (2010) terms a 'privatisation of policy delivery' with the expectation that wider social and economic outcomes will emerge through changing cultures and individual practices rather than through more collective welfare interventions or strong forms of regulation. Thus despite the pragmatic and positive discourse promoted within many policy frameworks, there is also a gradual erosion taking place in programmes that target specific groups for additional support. Such sentiments were highlighted by a GLA member who, in interview, noted that London's citizens possess a:

... commonality in their aspirations...[that] are the same as everybody else....I don't see diversity as being an important factor in that because we want the best for our families and it doesn't matter what our background is and that premise informs policy the most.

When questioned about diverse identities and social policy, some GLA interviewees claimed that the emphasis is now on supporting 'all citizens' or 'all businesses', not just those from certain backgrounds. It has become a "needs driven agenda" in which, as one civil servant remarked, "we never even talk about nationality" or the "experiences of different groups". Despite the widespread discourse that narratives of diversity in London 'differ' significantly from more integrationist agendas found across England and much of Europe, there is evidence here of an openly integrationist agenda emerging within the city, under the guise of pragmatic realism.

The politicization of diversity agendas has also generated new sets of conflicts over its core meanings and implications for urban development. A range of evidence shows that new forms of political challenge to dominant policy agendas are emerging across the city, some of which relate to issues of cultural representation but many of which are attacking the material changes to the built environment being made in the name of creative class and diversity-friendly urban policy. The London Plan 2011, for instance, claims that future policy will look to 'groups, or communities to find consensual strategies or common grounds on which they can work together to create a united vision and sense of belonging" (paragraph 3.4). If this is done effectively then diverse individuals and groups will be able to contribute to the formation of 'sustainable and cohesive' communities 'built on bonds that unite rather than the differences that separate' (ibid.). The narrative is one of consensus-building and an urban policy that enables citizens:

'to realise their potential and aspirations, make a full contribution to the economic success of their city - and share its benefits - while tackling problems of deprivation, exclusion and discrimination that impede them' (paragraph 3.3). 
Under Mayor Johnson this was rationalised through a new language of 'convergence' in which it is imagined that the planning system will facilitate growth and implement programmes so that 'over the next 20 years... [they] will come to enjoy the same life chances as other Londoners' (GLA, 2010: p.1).

The deflection of attention away from more structural causes of inequality also serves to institutionalise more voluntarist approaches to the delivery of urban policy objectives and the rolling of new forms of politicised managerialism. A series of piecemeal measures have been introduced to encourage public and private sector employers to establish 'diversity-awareness' in their recruitment practices in the belief that this will help bring to fruition policy objectives in a pragmatic way, with a minimum of resource input. Partnerships with charitable organisations, such as Business in the Community, have been established to help firms put into place what one interviewee referred to as "action plans on how they [employers] can diversify". There is no discourse of regulatory compulsion or US-style 'affirmative action' programmes. The GLA work closely with such organisations to try and encourage them, in the words of an interviewee, "to take action on recruitment and progression because although ethnic minority people are in the workforce, they're concentrated at lower levels" or to "improve the gender balance" within the decision-making structures of firms. Firms 'benchmark' their activities to demonstrate to their shareholders and to NGOs that they are working to boost the employment of different groups. The argument is used that by being more diverse, businesses will be able to benefit from a broader set of knowledge and skills, both in terms of company practices and through tapping into new market opportunities. There are also limited efforts to use contracting processes and 'smarter procurement' to support diversity and equality. The publication of the strategy Unlocking Public V alue: Leading London to Smarter Procurement has sought to institutionalise this programme, along with a new database service named CompeteFor (2014) that was setup to help smaller businesses and businesses led by those with diverse ethnic backgrounds access state contracts.

A second effect is that the celebration of diversity becomes a part of a wider collection of narratives that support an aggressive politics of development planning that is creating entrenched forms of class-based diversity and new separations. There is an emphasis on the right types of spatial ordering of diversity so that, as The London Plan 2011 explicitly states:

'Communities mixed and balanced by tenure and housebold income should be promoted across London through incremental small scale as well as larger scale developments which foster social diversity, redress social exclusion and strengthen communities' sense of responsibility for, and identity with, their neighbourboods. They must be supported by effective and attractive design, adequate infrastructure and an enhanced environment' (GLA, 2011c: Policy 3.9).

The rationale is familiar. It is based on the sociological notion of 'neighbourhood effects' which hypothesises that a high concentration of poor, or ethnic minority, people in specific areas is bad, as it reinforces and perpetuates poverty and exclusion and reduces opportunities for social mobility. The how of diversity based politics is to produce planning arrangements that create 'a more balanced mix of tenures...in all parts of London, particularly in some neighbourboods where social renting predominates and there are concentrations of deprivation' (ibid.). Mixed and balanced communities, it is argued, encourage co-presence and social encounters, which in turn can also facilitate social mobility and creativity through new interactions and the formation of diverse social networks.

These narratives are used to seek out and legitimate inward investment projects and have helped to fuel an explosion in globally-oriented contemporary developments to cater for elite global investors. Despite the celebration of London as a crucible of spatialized diversity, there is little capacity in the planning system to engineer the outcomes of new projects and investments to meet this end. Interventions are coordinated and organised on the level of individual applications and their 'viability' for private developers 
(see GLA, 2011c: Section 3.50). Under Planning Gain agreements permission is granted only if developers agree to various social investments and the provision of affordable ${ }^{8}$ housing and/or the provision of specific 'public' spaces. There is little strategic overview of this process or a focus on facilitating the movement of lower income residents into richer neighbourhoods. There is an absence of other forms of intervention to 'protect' the existing social composition of urban areas which are mixed but have become rapidly gentrified. Changes in planning frameworks are, therefore, running directly counter to the mixed communities and diversity narratives. They are creating urban spaces in which there is less spatially juxtaposed diversity and what Fincher and Iveson (2008) term spaces of encounter (see also Imrie and Lees, 2014). As the Social Integration Commission (2015) notes, this is part of a wider trend in which new separations are becoming embedded in the design and planning of British cities.

The impacts of these changes are significant for a range of social and economic groups in the city, from a variety of social and cultural backgrounds. Rising land and property prices, and the exclusive nature of new developments, are limiting the opportunities for smaller businesses and entrepreneurs to set themselves up in London and this is leading to a shrinkage in the diversity of London's business and employment base (see Ferm and Jones, 2015; Kesten et al., 2016). New developments are also leading to a gradual reduction in the availability of spaces for diverse encounters as public spaces are increasingly subject to private control (see Minton, 2014; Turner, 2015). Calls for the protection, or promotion, of diverse spaces and forms of encounter have acted as a lightning-rod for broader conflicts in the city and have fostered new types of conflictual politicisation. Disparate groups promote very different visions of what a diverse city should be and should become, with visions and views that differ markedly from those outlined in the celebratory narratives of diversity put forward in development frameworks (see for example Just Space, 2016; Games Monitor, 2016; Our Tottenham, 2015). As the economies of many western cities become more open to global investment flows and their populations continue to evolve in the wake of global movements of labour and migrants, so the forms of politicisation that narratives of diversity take will become of greater importance.

So overall, whilst there has been a willingness to recognise and politicise some selected dimensions of surrounding urban planning and its impacts on diversity in London, more structural concerns are given little or no attention or are presented as problems that will be tackled through voluntary actions and market-led solutions. Diversity has become synonymous with London's external appeal to investors and calls for existing employers to change their employment practices and think more about the recruitment of diverse groups. The much more difficult and contested issues surrounding the diversity of outcomes that result from contemporary forms of capitalist growth and the emergence of class-based divisions and diversity are not seen as problems that can be addressed directly through urban planning tools and public policy restrictions. As noted earlier, there is a Whiggish assumption that social and economic divisions will melt away as the city becomes more diverse and its politics more progressive in the longer term. Objectives have tended to remain aspirational and implicit and focussed on the indirect economic dividends associated with diversity policy, rather than the mechanisms through which redistribution takes place. There are no formal narratives that argue that inequality can be tackled by sanctions and taxes on the better off in London and/or on super-wealthy immigrants who are attracted to London's global property and asset markets. Instead diversity imaginations have become commodified and used to legitimate wider agendas of globally-focussed economic development. This in turn is leading to heightened spatial separation between different groups, or even in some cases the exclusion of certain classes from urban spaces and places.

${ }^{8}$ Affordable housing in London is defined as housing of $80 \%$ of market value, either to buy or rent. 


\section{Conclusions}

This paper has drawn on the example of diversity governance in London to examine the processes of politicisation that shape the politics of contemporary cities. It has built on Latour's (2007) core insight that an understanding of urban political processes requires an examination of the what and the how of politics or an evaluation of those aspects of a specific issue that become political (and which do not) and the ways in which these influence the form and character of urban political debate and policy frameworks. Whilst much has been written on 'post-politics' and 'critical pragmatism' in recent contributions to urban studies, the paper has argued for a more open framework that explores the synchronic and multiple forms of politicisation that take place in cities, the ways in which these operate, and with what effects. Latour's framework, we argue, establishes a particularly powerful methodological and analytical framework that is also able to capture the dynamic and, at times, turbulent processes through which specific forms of de- and repoliticisation takes shape in cities.

Critical research should therefore explore not only how agendas are constructed, but also by whom, for what purpose and with what ends. Projects should move away from the often-made assumption that contemporary cities and societies have become so complex that they are 'ungovernable' or that globalisation pressures make urban political and policy choices increasingly irrelevant. As Le Galès and Vitale (2013) argue the process of governing a city is never fully complete, nor linear and urban societies and economies are more or less governed and are always a work in progress. By adopting these Latourian approaches critical research can avoid some of the dangers associated with recent writings on 'neo-liberal' or 'post-political' cities that tend to play down these multiple sources of contestation and resolution and at their worst conform to what Le Galès (2016) describes as 'all-encompassing constructivist definitions that lead to confusion, over generalization, and vague understandings of mechanisms or processes' (p.168). Attempts by elite interests to remove topics or subjects from the political sphere of public engagement do not simply represent forms of de-politicisation, but constitute modes of re-politicisation embedded in relations of power and resources (such as discursive, economic, cultural etc.).

In this paper, the mechanisms in and through which diversity narratives and representations have been politicised provide a graphic example of such processes in action and the, at times, chaotic and open character of urban politics. Diversity is presented as both an object of governance, whose selective presence should be carefully crafted and shaped by policy interventions, and a subject that possesses the causal power to help bring about policy objectives, such as economic growth, the creation of modern and vibrant urban cultures, or the establishment of globally competitive, creative urban economies. There have been significant attempts to convert this narrative into a form of 'pragmatic' politicisation or a governmentality of normality and commonplace living that lacks a 'critical' or transgressive dimension. Diversity's 'contributions' to city living and economic growth become converted into the common-sense 'what' of politics. Tolerant/liberal agendas are put centre-stage around which constellations of actors can form agreement and consensus, including business groups, trade unions, developers, and charities. At the same time the 'how' of diversity planning has been elided with the building of 'talent-rich' labour markets and the creation of business-friendly environments. We have shown that during the last decade celebratory narratives have co-evolved with an aggressive and globally-focussed urban policy that has generated growth that enriches a relatively small minority of investors, many of whom reside overseas and have few connections to the city. We, therefore, concur with critics of uses of the term diversity (or other recent consensual governmental constructs such as resilience, smartness, and sustainability), for whom it acts as one of a number of diversionary discourses that are used to shift attention away from the impacts of more structural processes of exploitative and divisive capitalist development (see Michaels, 2010). In London, and elsewhere, the narrative of 'diversity' has gone hand-in-hand with growing socio-economic inequalities and divisions. 
At the time of writing, the politics of diversity in London, and elsewhere in Europe, has taken a new turn. Diversity is becoming re-politicised in new and potentially very different ways. In London there have been some significant shifts in policy. In May 2016 Sadiq Khan was elected Mayor, the first openly Muslim Mayor of a major city in the UK. For many this has been presented as evidence of the London electorate's progressive views on diversity and the presence of a positive governmentality that embraces and values socio-cultural difference (see Haque, 2016; The Independent, 2016; Khan, 2016). The new Mayor's Manifesto seeks to re-politicise the governance of diversity with the stated ambition that 'London should be a global beacon of tolerance, acceptance, and respect' (The Labour Party, 2016: p.56). There is a degree of continuity with the agendas discussed in this paper, with socio-cultural diversity presented as an asset in a pragmatic manner. An explicit 'business case' for diversity and openness continues to feature strongly and the Mayor plans to set up a Business Advisory Board to give business voices a direct say on core policy arrangements. In echoes of the Johnson era it is stated, for instance, that the Mayor will work to 'challenge unfair visa rules which make it harder for London businesses to bring in the world's best talent, who in turn create future opportunities for Londoners' (p.13).

However, there are also contrasts with the previous regime and a re-focusing of the what and how of urban politics on to more explicitly divisive and critical terrains of public debate. Assumptions over the city's development and the limits of policy are being challenged, with an explicit attempt made to move core planning issues out of the de-politicised realms of governmental acceptance towards a more critical form of relational thinking. Greater recognition is being given to the divisive social and physical impacts of globally-financed investments in the built environment and what should be done to regulate and govern change in the name of a broader 'public interest'. The term diversity is not simply 'celebrated' but directly associated with the production of 'a fairer and more equal city', in marked contrast to the trickle-down rhetoric of earlier rounds of policy discussed above. It is now, for example, accepted that: 'For young families and individuals on average incomes, housing is increasingly unaffordable - with home ownership a distant dream. Social mobility is failing. In-work poverty is rising. Rocketing transport fares are making it more expensive to get to work or training' (p.4). The politically more conflictual terms of suffering 'discrimination' or being 'treated unfairly' are openly used to provide more structural explanations for inequality across the city, rather than an individualised focus on low aspirations and/or increased responsibilisation. The Mayor, for instance, labels himself a 'proud feminist' (p.55) in the pursuit of new equalities and whilst, of course, at the time of writing it is much too early to make any assessment of practice, the appointment of more women to key Executive positions in the Mayor's Office indicates more awareness of equality issues (see The Guardian, 2016).

The new Mayor and other policy-makers in London have also been faced with disruptions and challenges both within the UK and from across the EU and north America. The political settlements that have (albeit selectively) enabled flows of people, investment, and goods to move across national borders have come under growing strain. Across Europe recent terror attacks have cast doubt on existing and future policies and encouraged growing support amongst political groups who oppose the growth of sociocultural diversity. The outcome of the UK Referendum on membership of the European Union in June 2016, and the decision to vote Leave has exacerbated and re-politicised the policy framings and debates over diversity in London and elsewhere. The outcome was, in part, based on political campaigns that openly presented growing diversity as a 'threat' to social cohesion and economic well-being (see Vote Leave, 2016). Referendum voting patterns show that Leave votes were higher in areas in which there had been proportionately large and recent relative increases in external migration (see The Economist, 2016a). This was mainly in smaller towns and rural areas, as opposed to cities in which the presence of diversity is long established. Approximately $60 \%$ of votes in London (2.26million) were for Remain, a marked contrast to the rest of the English regions in which the majority voted clearly to Leave. In the aftermath 
of the vote, London's perceived 'exceptionalism' in social, economic, and political terms is increasingly presented as a problem and evidence of a fiercely divided national polity. The Economist (2016b) newspaper has even termed the city Londonia or a nation within a nation. Within the city it has also generated new divisions with the new Mayor outlining plans to tackle 'hate crimes', whilst maintaining existing social and economic links with the EU. The governance of diversity in the city is entering a new phase of politicisation. 


\section{Acknowledgements}

The authors would like to thank John Bannister and two anonymous referees for their thoughtful and systematic engagements with earlier drafts of the paper and the constructive and positive nature of their suggestions. Many thanks also to Claire Colomb, Tatiana Moreira de Souza, Tuna Tasan-Kok and other members of the DIVERCITIES consortium for their comments and encouragement, along with audiences at numerous conferences. And finally, we would also like to dedicate this paper to the late Ronald van Kempen (1958-2016) without whom this research would not have been possible. This project has received funding from the European Union's Seventh Framework Programme for research, technological development and demonstration under Grant Agreement No 319970 - DIVERCITIES. The views expressed in this publication are the sole responsibility of the authors and do not necessarily reflect the views of the European Commission. Responsibility for the final draft is the authors' alone. 


\section{References}

Ahmed, S. (2009) Embodying diversity: Problems and paradoxes for Black feminists, Race Ethnicity and Education, 12, 41-52.

Ahonen, P.,Tienari, J., Meriläinen, S. and Pullen, A. (2014) Hidden contexts and invisible power relations: A Foucauldian reading of diversity research, Human Relations, 67 (3), 263-286.

Anttonon, A., Häikiö, L. and Stefánsson, K. eds. (2012) Welfare State, Universalism and Diversity, Edward Elgar, London.

Atkinson, R. and Easthope, H. (2009) The Consequences of the Creative Class: The pursuit of creativity strategies in Australia's cities, International Journal of Urban and Regional Research, 33, 64-79.

Bauman, Z. (2003), Community: Seeking Safety in an Insecure World. Cambridge: Polity Press.

BBC News (2010), 'Merkel says German multicultural society has failed', http://www.bbc.co.uk/news/world-europe-11559451, 17th October 2010.

Beebeejaun, Y. (2012) Including the Excluded? Changing the Understandings of Ethnicity in Contemporary English Planning, Planning Theory and Practice, 13, 529-548.

Bourdieu, P. and Wacquant, L. (2006) 'The cunning of Imperialist Reason', in L. Wacquant (ed.) Pierre Bourdieu and Democratic Politics, Polity Press, Cambridge, pp.178-199.

Bridge, G. (2005), Reason in the City of Difference: Pragmatism, Communicative Action and Contemporary Urbanism. London: Routledge.

Clarke, J. and Newman, J. 'Brave new world? Anglo-American challenges to universalism' in Anttonon, A., Häikiö, L. and Stefánsson, K. eds. (2012) Welfare State, Universalism and Diversity, Edward Elgar, London, pp.90-105.

CompeteFor (2014). Accessed: http://www.competefor.com.

Crouch, C. (2009) The Strange Non-death of Neo-liberalism, Polity Press, Cambridge.

De Vries, G. (2007) What is political in Sub-politics? How Aristotle might help STS, Social Studies of Science, $37,781-809$.

Delanty, G. (2012), A cosmopolitan approach to the explanation of social change: social mechanisms, processes, modernity, Sociological Review, 60, 2, pp. 333-354.

DCLG (2012) Creating the Conditions for Integration, HMSO, London.

Dorling, D. (2011), Injustice - Why Social Inequality Exists. Bristol: Policy Press.

Douglass, M. (2012), Local City, Capital City or World City? Civil Society, the (Post-) Developmental State and the Globalization of Urban Space in Pacific Asia, in M. Steger (ed.) Globalization and Culture, Edward Elgar Publishing, Cheltenham.

[The] Economist (2016a) 'Explaining the Brexit vote'. July 16 ${ }^{\text {th }}$.

[The] Economist (2016b) 'Brexitland vesus Londonia - Britain increasingly looks like two countries, divided over globalisation’, July $2^{\text {nd }}$. 
European Commission (2010) World and European Sustainable Cities - Insights from EU Research, European Commission, Brussels.

Ferm, J. and Jones, E. (2015) London's Industrial Land: Cause for Concern? University College London, UK, accessed at: http://discovery.ucl.ac.uk/1461419/

Fincher, R. and Iveson, K. (2008), Planning and Diversity in the City: Redistribution, Recognition and Encounter. Basingstoke: Palgrave Macmillan.

Florida, R. (2014) The Rise of the Creative Class - Revisited, Basic Books, New York.

Forester, J. (2012) On the theory and practice of critical pragmatism: Deliberative practices and creative negotiations, Planning Theory, 12, 5-22.

Giddens, A. (2009) The Politics of Climate Change, Cambridge: Polity Press.

Glaeser, E. (2011) The Triumph of the City, Macmillan, London.

Greater London Authority (2011) The London Plan, GLA, London.

Greater London Authority (2013) Final Consolidated Budget, 2013-2014, GLA, London.

[The] Guardian (2015a) Economy draws more east Europeans to the UK, online Edition 19 February 2015.

[The] Guardian (2015b) '50\% rise in long-term-unemployed youngsters from UK ethnic minorities', Accessed at: http://www.theguardian.com/society/2015/mar/10/50-rise-in-long-term-unemployedyoungsters-from-uk-ethnic-minorities, 11 March 2015.

[The] Guardian (2016) Sadiq Khan puts women to the fore in latest appointments to mayoral team, accessed at https://www.theguardian.com/uk-news/davehillblog/2016/mav/24/sadiq-khan-putswomen-to-the-fore-in-latest-appointments-to-mayoral-team, 5 August 2016.

Hall, S. (2012) City, Street and Citizen: The measure of the ordinary, Routledge, London.

Hall, T. \& Hubbard, P. (1996) The entrepreneurial city: new urban politics, new urban geographies, Progress in Human Geography, 20, 153-174.

Haque, M. (2016) Sadiq Khan: London's First Muslim Mayor, accessed at: http://www.themuslimweekly.com/News/Details/31536, 5 August 2016.

Healey, P. (2009) The pragmatic tradition in planning thought, Journal of Planning Education and Research, 28, 277-292.

Imrie, R. and L. Lees (eds.) (2014), Sustainable London: The Future of a Global City. Bristol: Policy Press.

[The] Independent (2016) Sadiq Khan's victory: a triumph for a tolerant, open and diverse world city, accessed at: http://www.independent.co.uk/voices/sadiq-khans-victory-a-triumph-for-a-tolerant-openand-diverse-world-city-a7018381.html

Johnson, B. (2013) 2020 Vision - the Greatest City on Earth, Greater London Authority, London.

Just Space (2016) Towards a Community-Led London Plan, accessed at: https://justspacelondon.files.wordpress.com/2016/01/towardse280a6final.pdf, 28 March 2016. 
Kenis, A. and Mathijs, E. (2014) (De) politicising the local: The case of the Transition Towns movement in Flanders (Belgium). Journal of Rural Studies,34, 172-183.

Kesten, J., Raco, M. and Colomb, C., (2014) Governing Urban Diversity: Creating Social Cohesion, Social Mobility and Economic Performance in Today's Hyper-diversified Cities, European Commission, Brussels.

Keith, M. (2005) After the Cosmopolitan? Multicultural Cities and the Future of Racism, Taylor and Francis, London.

Kenis, A., \& Mathijs, E. (2014). (De) politicising the local: The case of the Transition Towns movement in Flanders (Belgium). Journal of Rural Studies, 34, 172-183.

Khan, S. (2016) The world can learn from London's togetherness and diversity, accessed at: http://www.thetimes.co.uk/redbox/topic/london-mayoral-elections/the-world-can-learn-from-londonstogetherness-and-diversity, 5 August 2016.

[The] Labour Party (2016) Sadiq Khan for London - A Manifesto for All Londoners, The Labour Party, London.

Latour, B. (2007) Turning around politics - a not on Gerard de Vries' paper, Social Studies of Science, 37, 811-820.

Lauring, J. (2009) Managing cultural diversity and the process of knowledge sharing: A case from Denmark, Scandinavian Journal of Management, 25, 385-394.

Le Galès, P. and Vitale, T. (2013) Governing the Large Metropolis. A Research agenda, Working papers $d u$ Programme Cities are back in town, 2013-8, Paris, Sciences Po.

Le Galès, P. (2016) Neolieralism and urban change: Stretching a good idea too far?, Territory, Politics, Governance, 4, pp.154-172.

London First (2015) A Manifesto for Jobs and Growth - Making London the Best City in the World in Which to do Business, London First, London.

MacDonald, H. (2015) 'Fantasies of Consensus:' Planning Reform in Sydney, 2005-2013, Planning Practice \& Research, 30, 115-138.

Marres, N. (2007) The issues deserve more credit: Pragmatist contributions to the study of public involvement in controversy, Social Studies of Science, 37, 759-780.

Martin, R. (2015) Rebalancing the spatial economy: The challenge for regional theory, Territory, Politics, Governance, DOI: 10.1080/21622671.2015.1064825.

Massey, D. (2007) World City, Sage, London.

Metzger, J., Allmendinger, P. \& S. Oosterlynck, eds (2014) Planning Against the Political: Democratic Deficits in Contemporary European Territorial Governance, Routledge, London.

Michaels, W-B. (2008) The Trouble With Diversity, MacMillan, London.

Minton, A. (2012) Ground Control - Fear and Happiness in the Twenty-First Century City - second edition, Penguin, London. 
Nathan, M. (2015) After Florida: Towards an economics of diversity, European Urban and Regional Studies, 22: 3-19.

Neal, S., Bloch, A. and Solomos, J. (2013) Race, Multiculture and Social Policy in Britain, Palgrave, London.

Neves, J. and Melé, (2013) Managing Ethically Cultural Diversity: Learning from Thomas Aquinas, Journal of Business Ethics, 116, 769-780.

The New Statesman (2014) 'UKIP has won the European elections', accessed at: http://www.newstatesman.com/politics/2014/05/ukip-has-won-european-elections, 8 February 2015

Purcell, M. (2013) The Down-deep Delight of Democracy, Oxford University Press, Oxford.

Radaelli, C. (1999) Technocracy in the European Union, Longman, London.

Rancière, J. (2006) Hatred of Democracy, Verso, London.

Rorty, R. (1998) Philosophies of Social Hope, Penguin, New York.

Saeys, A., Albeda, Y., van Puymbroeck, N., Oosterlynck, S., Verschraegen, G., and Dierckx, D. (2014) Urban Policies on Diversity in Antwerp, Belgium, http://www.urbandivercities.eu/wpcontent/uploads/2013/05/Urban-Policies-on-Diversity-in-Antwerp.pdf, accessed 12 August 2015.

Scott, A. and Storper, M. (2015) The nature of cities: The scope and limits of urban theory, International Journal of Urban and Regional Research, 39, 1-15.

Silk, M. (2011) 'Towards a sociological analysis of London 2012', Sociology, Special Issue: Sociology and the 2012 Olympic Games, 45(5) p. 733-748.

Social Integration Commission (2015) Kingdom United? Thirteen Steps to Tackle Social Segregation, SIC, London.

Swan, E. (2010) Commodity Diversity: Smiling Faces as a Strategy of Containment, Organisation, 1, 77100 .

Swyngedouw, E. (2009) The Antinomies of the Postpolitical City: In Search of a Democratic Politics of Environmental Production, International Journal of Urban and Regional Research, 33, 601-620.

Swyngedouw, E. (2015) Liquid Power. MIT Press, Cambridge.

Syrett, S. and Sepulveda, L. (2012) Realising the diversity dividend: population diversity and urban economic development, Environment and Planning A, 43, 487 - 504.

Tasan-Kok, M., Kempen R van, Raco, M. and Bolt, G. (2013) Towards hyper-diversified European cities: A critical literature review, European Commission, Brussels.

Trust for London (2013) Hard Times, New Directions? The Impact of the Local Government Spending Cuts in London, accessed at: http://www.trustforlondon.org.uk/CASE LSE Summary London interim FINAL 171213\%5B3\%5D .pdf

Turner, G. [vs. DCLG and Shell] (2015) Approved Judgement - Royal Courts of Justice, Neutral Citation Number: [2015] EWHC 375 (Admin), HMSO, London. 
Urry, J. (2007) Mobilities, Polity Press, Cambridge.

Vertovec, S. (2007), Super-diversity and its implications, Ethnic and Racial Studies, 30, 1024-1054.

Vertovec, S. (2012), Diversity and the social imaginary, European Journal of Sociology, 53, pp. 287-312.

Vote Leave (2016) 'EU membership stops us controlling who comes into our country, on what terms, and who can be removed. The system is out of control', accessed at: http://www.voteleavetakecontrol.org/briefing.html, 12 August 2016.

Warrell, H. and Pickford, J. (2013) Boris Johnson proposes 'London visa' to boost tech start-ups, Financial Times, September 8th, accessed at: http://www.ft.com/cms/s/0/62459d68-1701-11e3-bced00144feabdc0.html\#axzz3S6sFYgRQ

Wessendorf, S. (2014) Commonplace Diversity. Social Relations in a Super-diverse Context, Palgrave Macmillan, Basingstoke.

Winter, A. (2013) 'Race, Multiculturalism and the 'Progressive' Politics of London 2012: Passing the 'Boyle Test', Sociological Research Online, 18, 18, accessed at: $<$ http://www.socresonline.org.uk/18/2/18.html> $10.5153 /$ sro.3069

Wilson, J. and Swyngedouw, E. (2014) eds. The Post-Political and its Discontents, Edinburgh University Press, Edinburgh.

World Economic Forum (2015) 'The Diversity Dividend' accessed at: http://www.weforum.org/sessions/summary/diversity-dividend

Žižek, S. (2011) Living in the End Times, Verso, London. 
2

Figure 1: Summary of Meanings of the Political

\begin{tabular}{|l|l|}
\hline Forms of Politicisation & Core Characteristics \\
\hline Relational Exchanges & $\begin{array}{l}\text { Political agendas and identities formed through the } \\
\text { relational interactions between different subjects. }\end{array}$ \\
\hline $\begin{array}{l}\text { Pragmatism/Critical } \\
\text { Pragmatism }\end{array}$ & $\begin{array}{l}\text { Issues become objects of political debate through } \\
\text { the actions of concerned publics and groups. }\end{array}$ \\
\hline $\begin{array}{l}\text { Public Management and } \\
\text { Bureaucracy }\end{array}$ & $\begin{array}{l}\text { Policy-making as technical-bureaucratic practice. } \\
\text { The exercise of sovereignty. }\end{array}$ \\
\hline The Co-production of Policy & $\begin{array}{l}\text { Policy-making a joint exercise of policy producers } \\
\text { and users. }\end{array}$ \\
\hline $\begin{array}{l}\text { Governmentality and De- } \\
\text { politicisation }\end{array}$ & $\begin{array}{l}\text { Processes of seeking to take issues out of the } \\
\text { political area. }\end{array}$ \\
\hline
\end{tabular}

Adapted from Latour (2007: p.7). 